\title{
IFRS adoption and cross border investment in Nigeria
}

\author{
Ini Etete Udofia ${ }^{\mathrm{a}, 1}$ \\ ${ }^{a}$ University of Lagos, Nigeria
}

\begin{abstract}
International Financial Reporting Standards (IFRS) has provided many benefits to developed countries globally. It is claimed to increase transparency, reduce information asymmetry and enhance cross border investment. This paper investigated the impact of IFRS adoption on cross border investment comprising of foreign portfolio investment and foreign direct investment in Nigeria from 20072016. The research employed a mixed research design comprising cross sectional survey and ex-post facto design using content analysis and inferential statistical tools. The study found that there is a positive perception from users and preparers of financial statements on the benefits derived from IFRS adoption in Nigeria. In addition, IFRS adoption impacts cross border investment in Nigeria. However, the pre adoption period had higher incidence of growth in FDIs and FPIs than the post adoption period. Consequently, IFRS adoption alone does not single handedly impact cross border investment but several other variables not considered in this study influence cross border investment in Nigeria. This paper recommends that the government of Nigeria should consider the improvement of institutional factors such as the legal, socio-political and macroeconomic milieu so as to enhance cross border investment in Nigeria.
\end{abstract}

Keywords: cross border investment, foreign portfolio investment, foreign direct investment, isomorphism, Nigeria

JEL codes: M41, M42.

${ }^{1}$ Doctoral student, Department of Accounting, University of Lagos, NIGERIA, Email: iniyang2005@yahoo.com 


\section{Introduction}

One of the ways the accounting profession has reacted to the evolution of transborder commercial activities is by working towards creating standards to unify accounting practice. This is seen as a step to encourage cross border investment that would allow the gains from the global economy to be fully realized. The International Accounting Standard Board (IASB) was tasked to create high quality standards (International Financial Reporting Standards (IFRS) that would unify accounting practices across borders, promote transparency and comparability of financial reports across borders; increase investors' confidence; reduce cost of capital as well as enhance cross border investment (Yip \& Young, 2012).

Even though the IFRS is purported to achieve the above listed points, studies have shown that the rate of achievement of these points vary among IFRS adopting countries (Ball et al., 2003). Furthermore, despite the highlighted benefits, the US has not adopted the IFRS yet on the premise that the cost of adoption far outweighs the benefits to be derived. Ball (2006) has shown that even with the enforcement of one set of accounting standards, the implementation among varying adopting countries will be based on their different economic, political and legal systems which might defeat the whole essence of the IFRS creation.

The market failure in 2008 which hit Europe despite their widely agreed adoption of IFRS in 2005 creates doubts about the perceived economic benefits of IFRS. Scholars have pointed out that for cross border investment to flow into any country especially developing countries such as Nigeria there must be a minimum threshold level of human capital, domestic infrastructures and local financial systems. It cannot be assumed, therefore, that compliance with any given set of standards will necessarily be beneficial (Okafor \& Ogiedu, 2011; Okpala, 2012). Nigeria adopted the IFRS for listed companies on the Nigerian Stock Exchange on $1^{\text {st }}$ of January 2012. Despite the adoption of IFRS, evidence has shown that the country's currency (Naira) has been reduced in value over time. Cross border investment has dropped drastically since 2012. This situation makes one wonder if IFRS adoption has not reduced information asymmetry in the Nigerian capital market or is it possible that other macroeconomic or political factors need to be addressed in order to increase Nigeria's foreign direct investment and foreign portfolio investment.

Taking cognizance of the rapidly changing global and financial environment, there is no current research on IFRS pre and post adoption impact on cross border investment comprising of Portfolio investment and foreign direct investment in Nigeria. Thus, this paper filled the research gap by investigating IFRS pre and post adoption impact on cross border investment comprising of foreign portfolio investment and foreign direct investment in Nigeria with the aid of both primary and secondary sources of data for analysis. The research employed a mixed research design comprising cross sectional survey and ex-post facto design using content analysis and inferential statistical tools. The study found that there is a positive 
perception from users and preparers of financial statements on the benefits derived from IFRS adoption in Nigeria. However, there was a statistically significant difference in the perceptions of preparers and users of financial reports on the perceived increase in cross border investment since the adoption of IFRS. It was observed that the pre adoption period had higher incidence of growth in Foreign Direct Investments and Foreign Portfolio Investments than the post adoption period. Consequently, IFRS adoption alone does not single handedly impact cross border investment in Nigeria.

The paper is structured as follows: section one presents the evolution of IFRS and benefits of adoption of IFRS globally. It describes the economic situation of the Nigerian capital market since the adoption of IFRS; section two presents empirical review of global and Nigerian perspectives to IFRS adoption and cross border investment, it provides a conceptual, regulatory and theoretical framework on IFRS adoption and cross border investment; section three presents the methodology adopted for the study and section four provides evidences from the field survey and content analysis of data. Lastly, section five summarises the main findings backed with findings from prior empirical studies, conclusion and recommendations for future studies.

\section{Literature review and hypotheses development}

Before the creation of the NASB (Nigerian Accounting Standard Board) in 1982, companies in Nigeria utilized any accounting measure that seemed suitable to them. Companies whose parents were resident outside Nigeria followed the dictates of their parents outside the shore of Nigeria, thereby, resulting in inconsistent accounting practices. In 2009, NASB made frantic efforts to adapt IFRSs to suit the changing Nigerian environmental peculiarities. This resulted in the promulgation of Financial Reporting Council of Nigeria Act of 2011. The Financial Reporting Council of Nigeria was charged with the regulation of accounting disclosure practice in Nigeria; facilitate the adoption of IFRS and to provide modifications where necessary to suit the Nigerian market.

Foreign Direct Investment (FDI) is a subset of foreign investment where the investors retain control over the investment. FDI shows that the owner of the money is coming to direct the affairs and has an effective voice in the management (Okpala, 2012), that is, the potential to influence or participate in the management of an enterprise. FDI typically takes the form of a foreigner setting up a subsidiary or taking over/control of an existing firm in the country in question. Foreign Portfolio Investment (FPI)is an investment in the form of debt or equity, which an investor lacks control over the investment. It typically takes the form of investments in financial assets such as bonds and stocks in which the investor does not have controlling interest. The major motivating factor is the favorable interest rate differential that is, capital flow from where it is plentiful to where it is scarce. Portfolio investment can equally be called FDI where an investor does not have to be involved in the management. 


\subsection{International perspectives on ifrs adoption and cross border investment}

The widespread adoption of IFRS increases financial information comparability, as firms move from varied domestic accounting standards toward a single set of standards (Yip \& Young, 2012). Increased comparability attracts foreign analyst following, cross-border investment (DeFond et al., 2011; Landsman et al., 2012; Tan et al., 2011) which would result in greater competition for capital from both domestic and international sources.

Past studies on the effect of IFRS adoption on cross border investment majorly in developed countries can be broadly categorized into two. Results in one category show how the adoption of IFRS has improved cross border investment in some countries and regions while the other category show results of how cross border investment is not necessarily influenced by the adoption of IFRS.

Cai and Wong (2010) studied the effect of IFRS adoption on global market integration, they examined the effect of IFRS adoption on the degree of integration of capital markets for the G8 countries: Canada, France, Germany, Italy, Japan, Russia, the UK and the US. Of these, the four EU countries were mandatory adopters during the period covered by the research (1995-2008). Integration was measured by the extent to which movements in the stock market indices for each country were correlated. Their result showed that all countries' stock markets showed an increasing level of international integration over time, but that, "compared to their non-adopting counterparts, the IFRS adopting countries seemed to enjoy a greater integration of their capital market after IFRS adoption'.

Márquez-Ramos (2011) carried a similar study with European countries using FDI data from 2002-2007. He provided evidence that positive benefits exist in terms of FDI when IFRS is adopted. However, a number of EU countries showed decrease in FDI from other EU Member States over the period.

Francis et al. (2012) examined the effect of mandatory IFRS adoption on crossborder merger and acquisition (M\&A) activity. They found that acquirers in countries that adopted IFRS increased their cross-border M\&A activity more postIFRS adoption in countries where there were larger differences in GAAP in the preIFRS period. This agrees with Bradley (1988) who posited that adoption of uniform, comparable and transparent accounting standards such as IFRS could remove obstacles to cross border acquisitions and divestitures at a premium to prospective investors.

Gordon et al. (2012) studied the impact of IFRS adoption on foreign direct investment in 124 countries (adopters and non-adopters; 14 from the EU) from19962008. They found support for the argument that overall FDI inflows are positively related with a country's decision to adopt IFRS. Their claim is statistically significant 
for those countries classified as developing economies, but not for countries classified as developed economies.

Ding et al. (2014) examined convergence of accounting standards and foreign direct investment, studying primarily the effects of convergence in relation to IFRS on FDI in the period 2000-2005. The sample covered 30 countries, 23 from the EU. The measure of FDI they used is the aggregate of in- and outflow between pairs of countries. They found out that, firstly, FDI flows are positively associated with conformity to IFRS. Secondly, the positive relationship between FDI and IFRS conformity is stronger for country pairs with greater institutional differences. Thirdly, FDI growth is positively associated with the degree of convergence from domestic accounting standards to IFRS during the period 2001 to 2005.

Lee and Neil (2010) looked at the effects of mandatory IFRS adoption on Australian investors' home equity bias. The sample comprised of 40 countries: 21 IFRS adopters (16 from the EU) and 19 non-adopters between 2002-2008. They found evidence which showed that the mandatory adoption of IFRS encouraged greater foreign investment for investors i.e., reducing bias against foreign equities.

Yu (2010) and De Fond et al. (2011) examined changes in mutual fund holdings in firms following mandatory adoption of IFRS. The sample comprised 4,399 firms, 650 voluntary IFRS adopters, 3,474 mandatory adopters, and 274 non-adopters (which form a control group) from 28 countries (nine non-EU) where IFRS was made mandatory. The period covered was 2000-2007. They both discovered that, following the mandatory IFRS adoption, the proportion of shares held by foreign mutual funds increased for mandatory adopters, more than voluntary adopters, and effectively remained unchanged for non-adopters.

Chen et al. (2015) studied the effect of mandatory IFRS adoption on international cross-listings. They discovered that firms that mandatorily adopted IFRS exhibited significantly higher cross listing propensity and intensity following IFRS adoption.

\subsection{Nigeria's perspective on ifrs adoption and cross border investment}

Nigeria is the third largest recipient of FDI in Africa after Angola and Egypt (Okpala, 2012). The perceived benefits of adopting IFRS were used in an attempt to increase the confidence level of various stakeholders in the country. It was argued that the benefits of adoption and implementation would outweigh the costs of implementation (Iyoha \& Faboyede, 2011). These presumed benefits included enhancement of local and foreign investors' confidence in the quality assurance systems of financial reporting in the public and private sector entities in Nigeria; which would lead to increase in Foreign Direct Investment and assurance of easier access to external capital; more meaningful and decision enhancing information attributed to the involvement of Accounting, Actuarial, Valuation and Auditing 
professionals as well as regulation and monitoring by the Financial Reporting Council of Nigeria (Josiah et al., 2013).

Eromosele (2015) revealed that IFRS implementation in Nigeria would ensure the integrity of the capital market, in the area of implied cost of equity capital, the frequency of zero-return days, the price impact of trades and cost of capital efficiency. He further added that IFRS would reduce manipulation of earnings, positively enhance stock market activities, impact on entity's stock returns and financial performance measures. Casmir (2015) posited that effective financial reporting is a stimulant for the capital market mechanism which the adoption of IFRS would create. Onipe et al. (2015) and Emeni et al. (2016) examined the adoption of IFRS and value relevance of accounting information of listed deposit money banks in Nigeria. These studies discovered that adoption of IFRS had improved the relevance of accounting numbers in the deposit money banking sector with the use of return and price regression models. Okpala (2012) investigated the effect of IFRS adoption on FDI and Nigerian economy. He found that respondents perceived that IFRS implementation would promote FDI inflows and economic growth.

Coercive and Mimetic isomorphism refer to pressures to obey rules and regulations issued by authoritative bodies or organizations (DiMaggio \& Powell, 1983). These pressures are characterized by means of authority and coercive power. Regulations issued by the Corporate Affairs Commission and the Financial Reporting Council of Nigeria, professional bodies- local and foreign are examples of pressures around financial reporting practice in Nigeria. The intense pressures and publication of the need to adopt IFRS by these authorities have convinced users and preparers of financial statements in Nigeria, albeit the lack of substantial or empirical evidence of the perceived benefits of adopting IFRS on cross border investment in Nigeria's economy. Contrary to these pressures and perceived expectations derivable from the adoption of IFRS in Nigeria, the growth in FDIs and FPIs from 2007-2016 has been minimal. Figure 1 below shows the sharp decline in these indices post adoption of IFRS.

Figure 1: FDI and FPI evolution

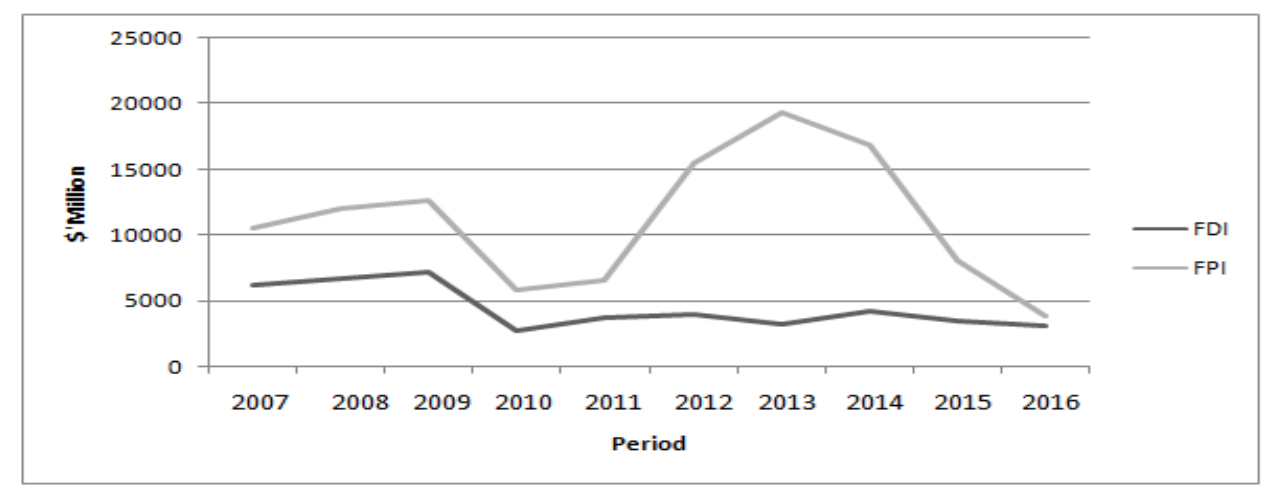


In view of these statistics, the following null hypotheses were developed for testing:

i. IFRS adoption in Nigeria has no significant impact on foreign portfolio investment in Nigeria.

ii. There is no significant relationship between IFRS adoption and foreign direct investment in Nigeria.

\subsection{Conceptual model}

Consequent upon the review of the prior literature, the chart in Figure 1 and the two hypotheses developed. There is need to develop a conceptual model to depict the impact of IFRS adoption on cross border investment in Nigeria. A model of the study is displayed in Figure 2.

Figure 2: IFRS adoption and cross border investment

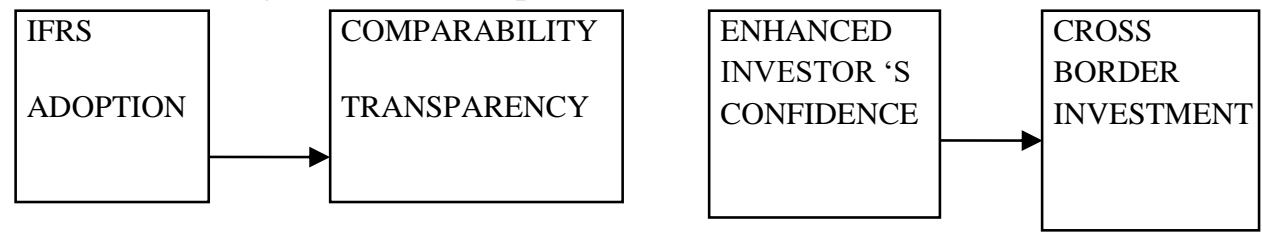

IFRS has been identified by many studies (Barth et al., 2011; DeFond et al., 2011) to improve transparency in the preparation of financial statement, comparability across borders, boost both local and international investors' confidence and subsequently improve cross border investment i.e. foreign portfolio investment and foreign direct investment. Studies have shown that this is possible because the promotion of IFRS across various countries will enhance its comparability across borders that have adopted the IFRS set of standards. Nigeria in line with isomorphic expectations believed that these same benefits would accrue to the Nation once IFRS is adopted.

\section{Research methods}

Survey and Ex-post facto research design were adopted for this study. Primary data were sourced from the perceptions of qualified financial and student members of the Institute of Chartered Accountants of Nigeria (ICAN) due to their knowledge on IFRS. The Nigerian Bureau of Statistics report on foreign direct investment and portfolio investment for Nigeria were sourced for information on Nigeria's cross border investment. 540 copies of a Likert scale structured questionnaire were administered using the convenience sampling method to professional students and members of the ICAN. The quarterly reports retrieved from the Nigeria Bureau of Statistics, were content analysed for data on cross border investments from the period 2007 to 2016.A total of 489 responses were retrieved. The response rate (91\%) was considered quite high and could be attributed to the administration of questionnaire 
copies during the Annual General Meeting of the members of the Institute as well as the distribution to Tuition houses which provided classes to students preparing for the ICAN qualifying exams in May. Other studies which have had high response rates include: Adeyemi et al. (2012). A pilot study was conducted using 15 respondents and their opinions were tested for reliability using the Cronbach alpha test, the result was 0.743 which showed that the instrument appeared reliable (Fields, 2009).

Descriptive and inferential statistical tools were used in analyzing the data collected. The descriptive statistical tools employed were tables and charts. The responses from the administered questionnaire were first converted to codes, ranging from 4-1 for Strongly Agree to Strongly Disagree respectively. It is these calculated set of values that were used for descriptive analyses. Secondary data obtained from the annual reports of cross border investment during the pre and post IFRS regime were analysed using the independent t-test. The results were used to test the hypotheses at $5 \%$ and $10 \%$ levels of significance.

Theoretically, IFRS adoption promotes transparency and comparability of financial statements across borders, which leads to increased cross border investment i.e. increase in foreign direct investment and foreign portfolio investment. Therefore it is theoretically right to say that foreign portfolio investment will increase, when IFRS is adopted. Therefore in testing hypotheses I and II it can be right to say that a positive relationship is expected between IFRS adoption and cross border investment (i.e. $\beta_{1}>0$ ).

Table 1: Measurement of variables

\begin{tabular}{llll}
\hline Variable & \multicolumn{1}{c}{ Source of data } & \multicolumn{1}{c}{ Measurement } \\
\hline \multirow{2}{*}{ IFRS } & $\begin{array}{l}\text { International Financial } \\
\text { Reporting Standards } \\
\text { adoption }\end{array}$ & $\begin{array}{l}\text { Period of pre and post } \\
\text { adoption of IFRS }\end{array}$ & $\begin{array}{l}\text { 1= post adoption of IFRS } \\
\text { 0= pre-adoption of IFRS }\end{array}$ \\
FPI & $\begin{array}{l}\text { Foreign Portfolio } \\
\text { investment }\end{array}$ & $\begin{array}{l}\text { Nigeria Bureau } \\
\text { of Statistics report }\end{array}$ & $\begin{array}{l}\text { amount of FPIs from } \\
2007-2016\end{array}$ \\
\multirow{2}{*}{ FDI } & Foreign direct investment & $\begin{array}{l}\text { Nigeria Bureau of } \\
\text { Statistics report }\end{array}$ & $\begin{array}{l}\text { amount of FDIs from } \\
\text { 2007-2016 }\end{array}$ \\
\hline
\end{tabular}

\section{Data presentation and analysis}

A total number of 540 copies of the questionnaire were administered. However, only 489 copies of the questionnaire were retrieved which shows a high response rate of about $92 \%$ percent. The demographic details of respondents are displayed in Table 2. 
Table 2: Demographic details of respondents

\begin{tabular}{llcc}
\hline & \multicolumn{1}{c}{ Description } & Frequency & Percent \\
\hline Respondents' Years of & Below 5 Years & 279 & 57.1 \\
service in the & Between 5-10 Years & 142 & 29.0 \\
organization & Above 10 Years & 68 & 13.9 \\
& Total & 489 & 100.0 \\
Professional & Fellow Chartered Accountants & 69 & 14.1 \\
Qualification of & member & & \\
Respondents & Associate Chartered & 231 & 47.3 \\
& Accountant member & & \\
& Professional level student & 3 & 0.6 \\
& member & 111 & 22.7 \\
& Skill level student member & 75 & 15.3 \\
& Intermediate level student & 489 & 100.0 \\
& member & 380 & 77.7 \\
Respondents' & Total & 109 & 22.3 \\
Interaction with & Preparer & 489 & 100.0 \\
\hline
\end{tabular}

From the Table 2 above, majority of the respondents have working experience of five years and below which accounted for approximately $57 \%$ of the total respondents sampled. Most of the respondents were qualified Chartered Accountants which accounts for approximately $61 \%$ of the total respondents sampled. In addition, majority of the respondents sampled $(78 \%)$ were preparers of financial statement in Nigeria, while 109 (22\%) were users of financial statements.

\subsection{The relationship between IFRS adoption and portfolio investment in Nigeria}

\section{Analysis of survey data}

Items 6 to 8 on the questionnaire were used to analyse this relationship. The responses are displayed in Tables 3 and 4 .

Table 3: Relationship between IFRS adoption and portfolio investment in Nigeria

\begin{tabular}{|c|c|c|c|c|c|c|c|}
\hline Statement & $\begin{array}{c}\text { Total } \\
\mathbf{N} \\
\end{array}$ & Mean & Median & $\begin{array}{c}\text { Std. } \\
\text { Deviation }\end{array}$ & Agree & Neutral & Disagree \\
\hline $\begin{array}{l}\text { There is a } \\
\text { relationship } \\
\text { between IFRS } \\
\text { and portfolio } \\
\text { investment in } \\
\text { Nigeria }\end{array}$ & 489 & 3.255 & 3 & 0.7 & $92.8 \%$ & $3.9 \%$ & $3.3 \%$ \\
\hline $\begin{array}{l}\text { Since the } \\
\text { adoption of IFRS }\end{array}$ & 489 & 2.074 & 2 & 1.137 & $44.8 \%$ & $48.1 \%$ & $7.1 \%$ \\
\hline
\end{tabular}

Vol. 17, No. 4 


\begin{tabular}{|c|c|c|c|c|c|c|c|}
\hline Statement & $\begin{array}{c}\text { Total } \\
\mathbf{N}\end{array}$ & Mean & Median & $\begin{array}{c}\text { Std. } \\
\text { Deviation }\end{array}$ & Agree & Neutral & Disagree \\
\hline $\begin{array}{l}\text { in Nigeria, there } \\
\text { has been an } \\
\text { increase in the } \\
\text { foreign } \\
\text { participation of } \\
\text { non-controlling } \\
\text { equity in Nigeria } \\
\text { The level of } \\
\text { portfolio } \\
\text { investment in } \\
\text { Nigeria is } \\
\text { determined to a } \\
\text { great extent by } \\
\text { the financial } \\
\text { reports prepared } \\
\text { and published in } \\
\text { Nigeria }\end{array}$ & 489 & 3.268 & 3 & 0.707 & $91.5 \%$ & $2.2 \%$ & $6.3 \%$ \\
\hline
\end{tabular}

From Table 3 above, majority of the respondents with a mean value of 3.25 (on a 4-point Likert scale) agreed that there is a relationship between IFRS adoption and portfolio investment in Nigeria. The analysis also showed a mean value of 2.07 which appears as if opinions are somewhat divided among respondents. A total of 219 respondents $(44.8 \%)$ agreed that since the adoption of IFRS in Nigeria, there have been an increase in the foreign participation of non-controlling equity in Nigeria, while majority of the respondents $(7.1 \%)$ disagreed. The mean value of 3.26 (on a 4-point Likert scale) suggests that most of the respondents (91.5\%) agreed that the level of portfolio investment in Nigeria is determined to a great extent by the financial reports prepared and published in Nigeria.

Table 4: Group statistics on perceptions of respondents on IFRS adoption and FPIs

\begin{tabular}{|c|c|c|c|c|c|}
\hline & $\begin{array}{l}\text { Preparer } \\
\text { or user }\end{array}$ & $\mathbf{N}$ & Mean & $\begin{array}{c}\text { Std. } \\
\text { Deviation }\end{array}$ & $\begin{array}{l}\text { Std. Error } \\
\text { Mean }\end{array}$ \\
\hline There is a relationship between IFRS & preparer & 380 & 3.268 & 0.763 & 0.039 \\
\hline and portfolio investment in Nigeria & user & 109 & 3.211 & 0.410 & 0.039 \\
\hline $\begin{array}{l}\text { Since the adoption of IFRS in Nigeria, } \\
\text { there has been an increase in the }\end{array}$ & preparer & 380 & 2.261 & 1.148 & 0.059 \\
\hline $\begin{array}{l}\text { foreign participation of non-controlling } \\
\text { equity in Nigeria }\end{array}$ & user & 109 & 1.422 & .820 & 0.079 \\
\hline $\begin{array}{l}\text { The level of portfolio investment in } \\
\text { Nigeria is determined to a great extent }\end{array}$ & preparer & 380 & 3.284 & .771 & 0.039 \\
\hline $\begin{array}{l}\text { by the financial reports prepared and } \\
\text { published in Nigeria }\end{array}$ & user & 109 & 3.211 & .410 & 0.039 \\
\hline
\end{tabular}

The results in Table 4 showed that both users and preparers agreed that there is a relationship between IFRS adoption and portfolio investment (Mean=3.268; and Mean=3.211 respectively) (on a 4-point Likert scale). Furthermore, they both agreed that the level of portfolio investment in Nigeria is determined by the preparation and 
publication of financial reports in Nigeria (Mean =3.284; Mean=3.211). However, the users disagreed that IFRS adoption had increased foreign participation of non controlling equity in Nigeria, while prepares weakly agreed to this assertion. In order to test the extent of difference between users' and preparers' perceptions, Levene's test was conducted.

The results revealed that the difference was significant $t(241.78)=7.122, p<0.05$. Thus, one can infer that there is a significant difference in the opinions of preparers and users of financial reports on the growth of FPIs since the adoption of IFRS. Users opine that there are lower changes in foreign portfolio investment since adoption of IFRS, while the preparers think it otherwise. Consequently, IFRS adoption has a significant impact on foreign portfolio investment.

In order to analyse the extent to which the adoption of IFRS has influenced portfolio investment, secondary data obtained from the Nigerian bureau of Statistic on portfolio investment were analysed pre and post adoption of IFRS.

\section{Analysis of secondary data}

The sample period was classified into two- pre 2012 and post 2012. The pre 2012 period covered the use of Nigerian Accounting Standards (SAS) while; Post 2012 (2012-2016) was a period of adoption of IFRS with several revisions to other IFRSs subsequently so as to improve comparability and transparency. An independent t-test of the sample was carried out. The mean, standard deviation and t-test results are shown in Table 5.

Table 5: Group statistics

\begin{tabular}{llccrr}
\hline & Period of adoption & N & Mean & \multicolumn{1}{c}{$\begin{array}{c}\text { Std. } \\
\text { Deviation }\end{array}$} & $\begin{array}{c}\text { Std. Error } \\
\text { Mean }\end{array}$ \\
\hline Foreign & Pre adoption of IFRS & 20 & 1877.915 & 735.174 & 164.390 \\
Portfolio & Post adoption of & 20 & 2679.612 & 1746.508 & 390.531 \\
investment & IFRS & & & & \\
\hline
\end{tabular}

From table 5, it was observed that both periods 2007-2011 and 2012-2016 had 20 firm year observations each. The period 2007-2011 had a switch mean value of 1877.92. In other words, a lot of changes occurred in FPIs, with a standard deviation of 735.17, and standard error mean of 164.39. Whilst the average value for FPIs in 2012-2016 was 2679.61 which shows a slightly higher change (43\% increase) in FPIs compared to the pre IFRS adoption period, with a standard deviation of 1746.51 and standard error mean of 390.53 .

The Levene's test was used to check if the variances in portfolio investment are different between pre IFRS adoption and Post IFRS adoption revealed that Post 2012 period experienced greater foreign portfolio changes than Pre 2012. This difference 
was significant $t(25.528)=-1.892, p<0.05$. Thus, one can infer that the Post 2012 period is characterized by higher changes in foreign portfolio than the pre 2012 period. Consequently, IFRS adoption during 2012-2016 had a significant impact on foreign portfolio investment while Pre IFRS adoption had lesser impact on foreign portfolio investment. Thus, the null hypothesis is not retained which proposes that the adoption of IFRS in Nigeria has no relationship with foreign portfolio investment.

\subsection{The relationship between ifrs adoption and foreign direct investment in Nigeria}

\section{Analysis of survey data}

The responses of users of financial statements on relevant questionnaire items that would achieve this objective are displayed in Table 6.

Table 6: Relationship between IFRS adoption and foreign direct investment

\begin{tabular}{|c|c|c|c|c|c|c|c|}
\hline Statement & $\begin{array}{c}\text { Total } \\
\mathbf{N}\end{array}$ & Mean & Median & $\begin{array}{l}\text { Standard } \\
\text { Deviation }\end{array}$ & Agree & Neutral & Disagree \\
\hline $\begin{array}{l}\text { There is a } \\
\text { relationship } \\
\text { between IFRS and } \\
\text { foreign direct } \\
\text { investment in } \\
\text { Nigeria }\end{array}$ & 489 & 3.245 & 3 & 0.731 & $91 \%$ & $3.3 \%$ & $5.7 \%$ \\
\hline $\begin{array}{l}\text { Since the adoption } \\
\text { of IFRS in Nigeria, } \\
\text { there has been an } \\
\text { increase in the } \\
\text { foreign } \\
\text { participation of } \\
\text { controlling equity } \\
\text { in Nigeria }\end{array}$ & 489 & 2.078 & 2 & 1.153 & $43.6 \%$ & $47.4 \%$ & $9 \%$ \\
\hline $\begin{array}{l}\text { The level of foreign } \\
\text { direct investment in } \\
\text { Nigeria is } \\
\text { determined to a } \\
\text { great extent by the } \\
\text { financial reports } \\
\text { prepared and } \\
\text { published in } \\
\text { Nigeria }\end{array}$ & 489 & 3.172 & 3 & 0.776 & $87.3 \%$ & $4.2 \%$ & $8.5 \%$ \\
\hline
\end{tabular}

From Table 7 above, the analysis shows that showed that both users and preparers agreed that there is a relationship between IFRS adoption and foreign direct investment and the level of foreign direct investment in Nigeria is determined to a great extent by the financial reports prepared and published in Nigeria 
(Mean=3.245 and Mean=3.172 respectively). The group statistics results of users' and preparers' opinions are displayed in Table 7.

Table 7: Group statistics on respondents opinion on IFRS adoption and FDIs

\begin{tabular}{|c|c|c|c|c|c|}
\hline & $\begin{array}{l}\text { Preparer } \\
\text { or user }\end{array}$ & $\mathbf{N}$ & Mean & $\begin{array}{l}\text { Std. } \\
\text { Deviation }\end{array}$ & $\begin{array}{l}\text { Std. Error } \\
\text { Mean }\end{array}$ \\
\hline There is a relationship between IFRS and & preparer & 380 & 3.255 & 0.799 & 0.041 \\
\hline foreign direct investment in Nigeria & user & 109 & 3.2110 & 0.410 & 0.039 \\
\hline $\begin{array}{l}\text { Since the adoption of IFRS in Nigeria, } \\
\text { there has been an increase in the foreign }\end{array}$ & preparer & 380 & 2.2500 & 1.150 & 0.059 \\
\hline $\begin{array}{l}\text { participation of controlling equity in } \\
\text { Nigeria }\end{array}$ & user & 109 & 1.4771 & 0.949 & 0.091 \\
\hline $\begin{array}{l}\text { The level of foreign direct investment in } \\
\text { Nigeria is determined to a great extent by }\end{array}$ & preparer & 380 & 3.1842 & 0.833 & 0.043 \\
\hline $\begin{array}{l}\text { the financial reports prepared and } \\
\text { published in Nigeria }\end{array}$ & user & 109 & 3.1284 & 0.529 & 0.051 \\
\hline
\end{tabular}

Overall, the results show that preparers and users agree that there is a relationship between IFRS adoption and foreign direct investment (Mean=3.255; Mean=3.211). They both also agreed that the level of FDIs is determined to a large extent by the financial reports prepared and published in Nigeria (Mean=3.18 and Mean=3.12 respectively). However, the users disagreed that IFRS adoption had increased foreign participation of controlling equity in Nigeria, while preparers weakly agreed to this statement.

Levene's test was conducted to test the extent of difference between users' and preparers' perceptions on IFRS adoption and increase in FDIs. It was observed that $t(207.728)=6.417, p<0.05$. Thus, one can infer that there is a statistically significant difference in the opinions of preparers and users of financial reports on the growth of FDIs since the adoption of IFRS. Users opine that there are lower changes in foreign direct investments since adoption of IFRS, while the preparers think otherwise. Consequently, users and preparers differ in their opinion on the significant impact of IFRS adoption on foreign direct investment.

In order to corroborate the findings from the opinions of respondents, secondary data obtained from the Nigerian Bureau of Statistic on foreign direct investment were analysed pre and post adoption of IFRS to determine the influence of IFRS adoption on FDIs in Nigeria.

\section{Analysis of secondary data}

In the testing the relationship between IFRS and FDI, an independent t-test of the sample was carried out. The mean, standard deviation and t-test results are shown in Tables 8 and 9. 
Table 8: Group statistics

\begin{tabular}{llccrr}
\hline & Period of adoption & N & Mean & $\begin{array}{c}\text { Std. } \\
\text { Deviation }\end{array}$ & $\begin{array}{c}\text { Std. Error } \\
\text { Mean }\end{array}$ \\
\hline $\begin{array}{l}\text { Foreign Direct } \\
\text { Investment }\end{array}$ & $\begin{array}{l}\text { Pre adoption of } \\
\text { IFRS }\end{array}$ & 20 & 832.293 & 525.805 & 117.573 \\
& $\begin{array}{l}\text { Post adoption of } \\
\text { IFRS }\end{array}$ & 20 & 402.349 & 214.826 & 48.036 \\
\hline
\end{tabular}

From Table 8, it was observed that both periods 2007-2011 and 2012-2016 had 20 firm year observations each. The period 2007-2011 had a switch mean value of 832.292. In other words, a lot of changes occurred in FDIs, with a standard deviation of 525.81, and standard error mean of 117.57. Whilst, the average value for FDIs in 2012-2016 was 402.35 which shows a slightly higher change (52\% decrease) in FDI compared to the pre IFRS adoption period, with a standard deviation of 214.827 and standard error mean of 48.04 .

The Levene's test used to check if the variances in direct investment are significant at $p<0.05$, the results showed that on average, Pre 2012 period experienced greater foreign direct investment changes than Post 2012. This difference was significant $t$ $(3.385)=25.171, p<0.05$. Thus, one can infer that the Pre adoption of IFRS is characterized by higher changes in foreign direct investment than the post 2012 period. Consequently, IFRS adoption during 2012-2016 had a less significant impact on foreign direct investment while Pre IFRS adoption had more impact on foreign direct investment. Therefore, the null hypothesis which proposes that the adoption of IFRS in Nigeria has no significant impact on foreign direct investment is not retained.

\subsection{Discussion of findings}

Empirical findings from the independent t-test analysis of the annual data of foreign portfolio investment and foreign direct investments Pre and Post IFRS periods show that IFRS adoption has a significant impact on the foreign portfolio investment and foreign direct investment of Nigeria. These findings align with the perceptions of financial statement users on the influence of IFRS adoption on cross border investment. The findings agree with prior studies (Beuselinck et al., 2009; Chen et al., 2015; DeFond et al., 2011; Eromosele; 2015; Okpala, 2012; Yu, 2010). It also agrees with the theory of Coercive and Mimetic isomorphism because the pressures from established institutions on financial reporting practice in Nigeria especially the perceived benefits of IFRS adoption on cross border investments, have not taken cognizance of factors other than IFRS adoption which could influence cross border investment in Nigeria's economy. Consequently, the decline in cross border investments during the post IFRS adoption in Nigeria can be attributed to other factors beyond the scope of this study. 


\section{Conclusion}

With the global trend in the adoption of IFRS across continents, several studies have been carried out to examine the impact of IFRS adoption on performance and other economic growth. Many benefits have been claimed to be associated with the adoption of IFRS. It is evidenced to enhance transparency, reduce information asymmetry, enhance cross border investment among others.

Márquez-Ramos (2011), Francis et al. (2012) and Gordon et al. (2012) find evidence of increased levels of FDI and FPI following mandatory IFRS adoption, that is statistically significant for developed economies and less for developing economies. While their studies agree on an association between increased cross border investment and mandatory IFRS adoption, there are problems in knowing how robust their findings are with respect to developing countries such as Nigeria. While the findings of this study corroborate the results of prior studies, it is not clear how far other concurrent institutional changes in Nigeria may be attributable to increases or otherwise in cross border investment. In addition, the volume of change in Nigeria's cross border investment has dropped in recent years due to other factors such as education, legal system, socio-political and macroeconomic policies among others that cause varying results on the adoption of IFRS, it might be that some of these areas have not been strengthened before embracing IFRS adoption in Nigeria.

This study has shown that IFRS adoption impacts foreign portfolio investment and foreign direct investment in Nigeria. Companies in Nigeria are open to the idea of foreign portfolio investment and foreign direct investment inflow, but the fact is that IFRS adoption alone does not single handedly impact foreign portfolio investment and foreign direct investment but several other variables not considered in this study influence cross border investment. Survey and content analysis approaches were adopted in executing the objectives of this paper. The survey research entailed administering questionnaire to professional accountants and students knowledgeable of accounting information to provide responses on their perceptions of the impact of IFRS adoption on cross border investments. The Nigeria Bureau of Statistics reports were content analysed to gather data on the trend of portfolio investment and foreign direct investment from 2007 to 2016. This study will assist accounting regulators and accounting professional bodies to ascertain the relevance of IFRS adoption on cross border investment in Nigeria.

Developing countries in the world should not be in a hurry to adopt IFRS if the Nation is not structurally prepared for it. This is because; there must be an improvement in other aspects of the economy which impact Cross border investment. Such improvements include: growth in institutional and infrastructural structures, extraction and development of natural resources as well as ensuring that the GDP increases constantly. In addition to all these, security improvement will also lead to a welcome environment for foreign capital inflow. 
The Financial Reporting Council of Nigeria (FRCN), regulators of the stock market should also monitor compliance of companies with the requirements of the International Financial Reporting Standards as this might help organizations in the long run to secure either FPIs or FDIs as the case might be.

In conducting this research, primary and secondary sources of data were used. Some respondents were reluctant to fill the questionnaire (primary data), it is also probable that there would be insincere responses among the filled questionnaire. In addition, the questionnaire did not provide adequate options of the field of accounting specialization for respondents to select. Thus, the responses of auditors may have been included among the responses of Accountants who prepare or use financial statements. The accuracy of the secondary data would be subject to the sincerity and intentions for which the preparers developed it. In view of these limitations, future studies could expand the scope of respondents so as to accommodate more stakeholders. A wider time frame would provide a more detailed picture of the relationship between IFRS and cross border investment. Inclusion of other variables that could give a better representation of IFRS adoption can be looked into to enhance future studies on the subject matter.

\section{References}

Abata, A. A. (2015) „Impact of IFRS on financial reporting practices in Nigeria (A Case of KPMG)", Global Journal of Contemporary Research in Accounting, no.1: 263-283

Adetula, D. T., Nwobu, O., \& Owolabi, F. (2014) „International Financial Reporting Standards and Foreign Direct Investment in Nigeria", International Journal of Commerce, Business and Management, 446-449

Armstrong, C. S., Barth, M. E., Jagolinzer, A. D., \& Riedl, E. J. (2010) „Market reaction to the adoption of IFRS in Europe", The Accounting Review, vol. 85, no.1: 31-61

Ball, R. (2006) „International financial reporting standards (IFRS): pros and cons for investors", Accounting and Business Research, vol. 36: 5-27

Barth, M. E., Landsman, W. R., Lang, M. H. \& Williams, C. D. (2011) „Are IFRSbased and US AAP-based accounting amounts comparable?", Rock Center for Corporate Governance of Stanford University Working Paper No. 78

Beke, J. (2011) „How can international accounting standards support business management?" International Journal of Management and Business research, vol.1, no.1: 25-34

Bradley, M., Desai, A. and Kim, E. H. (1988) „Synergistic gains from corporate acquisitions and their division between the stockholders of target and acquiring firms", Journal of Financial Economics, no. 21: 3-40 
Cai, F. C., Wong, C. H. (2010) „The Effect of IFRS Adoption on Global Market Integration", International Journal of Business and Economics Research, vol.9, no. $10: 25-34$

Casmir, I. (2015) „,Teach yourself IFRS”, Lagos: Global Concept Publishers, 25-32

Chen, L.Ng, J., \&Tsang, A. (2015) „The Effect of Mandatory IFRS Adoption on International Cross-Listings", vol. 90: 1395-1435

Ding, Y., Chen, C. J. P. \& Xu, B. (2011) „Convergence of Accounting Standards and Foreign Direct Investment" (November 5, 2010), Finance and Corporate Governance Conference 2011 Paper. Available at http://dx.doi.org/10.2139/ssrn.1703549

DeFond, M. Hu, X., Hung, M., Li, S. (2011) „The impact of mandatory IFRS adoption on foreign mutual fund ownership: The role of comparability", Journal of Accounting and Economics, vol. 51, no. 3: 240-258

DiMaggio, P.J. \& Powell, W.W.(1983) „The iron cage revisited: institutional isomorphism and collective rationality in organizational fields". American Sociological Review, vol.48,no.2:147-160

Emeni, F., Uwuigbe, O., Uwuigbe, U. \& Erin, O. (2016) „The value relevance of adopting IFRS: Evidence from the Nigerian banking sector", Review of Economic Studies and Research, vol.11, no.2: 49-66

Ekeocha, P. C. (2008) „Modelling the long run determinants of foreign portfolio investment in an emerging market: evidence from Nigeria", International Conference on Applied Economics , pp. 289-286

Eromosele, A. (2012) „IFRS impact on the capital market”. Retrieved from http//www.thisdaylive.com

Falayi, I., \& Ibukun-Falayi, O. R. (2015) „Cross border accounting for optimal investment decision- how relevant is the IFRS", European Journal of Accounting, Auditing and Finance Research, vol.3, no.8: 42-51

Francis, Jere R. and Huang, Shawn X. and Khurana,\& Inder K. (2012) „The Role of International GAAP in Cross-Border Mergers and Acquisitions" (September 17, 2012), Available at SSRN: https://ssrn.com/abstract=2131472 or http://dx.doi.org/10.2139/ssrn.2131472

Gordon, L. A ., Loeb,M. P . \& Zhu, W. ( 2012) „The impact of IFRS adoption on foreign direct investment", Journal of Accounting and Public Policy, vol. 31, no. 4: 374-398

Jaweher, B., \& Mounira, B. A. (2014) „The effects of mandatory IAS/IFRS regulation on the properties of earnings' quality in Australia and Europe", European Journal of Business and Management, vol.6, no. 3: 92-111

Josiah, M., Okoye, A. E., and Adediran, O. S. (2013) „Accounting standards in Nigeria, the journey so far", Research Journal of Business Management and Accounting, vol. 2, no. 1: 1-10 
Klimczak, K. M. (2011) „Market reaction to mandatory IFRS adoption: Evidence from Poland", Accounting and Management Information Systems, vol. 10, no. 2: 228-248

Landsman, W.R., Maydew, E.L., \& Thornock, J.R. (2012) „The information content of annual earnings announcements and mandatory adoption of IFRS", Journal of Accounting and Economics, vol. 53, no. 1-2: 34-54

Lee, G., \& Fargher, N. (2010) „Did the adoption of IFRS encourage cross-border investment?", SSRN Electronic Journal, 1-21

Marquez-Ramos, L. (2008) „,The effect of IFRS adoption on trade and foreign direct investments", Spain: International Trade and Finance Association

Mikova, T. (2014) „Influence of IFRS on earnings manipulation: evidence from the European Union", STATI, 3-17

Okafor, C. \& Ogiedu, K.O. (2011) „Potential effects of the adoption and implementation of International Financial Reporting Standards (IFRS) in Nigeria", JORIND, vol.9, no. 2: 345-358

Okafor, C.O. and Okaro, G.O (2013) „Fair Value Accounting and Loan Loss Provisioning - Early Evidence from Nigerian Banking Industry", Research Journal of Finance and Accounting. vol.4, no. 8: 1-12

Okoye, P. V., \& Ezeijiofor, R. (2014) „The effect of adoption of IFRS on the stock performance: implications on investor's expectations", Research Journal of Finance and Accounting, vol.15, no.4:8-12

Okpala, K. E. (2012) „Adoption of IFRS and financial statements effects: the perceived implications on FDI and Nigeria economy", Australian Journal of Business and Management Research, vol.2, no.5: 76-83

Omneya, H. A.-E., \& Weetman, P. (2003) „Introducing international accounting standards to an emerging capital market: relative familarity and language effect in Egypt", Journal of International Accounting, Auditing \& Taxation, vol. 12: 63-84

Onalo, U., Lizam, M., \& Kaseri, A. (2014) „The effects of changes in accounting standards on earnings management of Malaysia and Nigeria banks", European Journal of Accounting Auditing and Finance Research, vol. 2, no. 8:15-42

Onipe, A., Onyabe, J. \& Usman, S. (2015) „IFRS adoption and value relevance of accounting information of listed deposit money banks in Nigeria", Journal of Economics and Sustainable Development, vol.6, no. 12: 85-93

Onulaka, P. N. (2014) „Impact of adoption of IFRS in Nigeria capital market, preparers of financial statements and auditors", International Journal of Science and Research, vol. 3, no. 11:149-158 
Onyali, C. I., \& Okafor, T. (2014) „Foreign Direct Investment and the Nigerian Economy: Vision 2020 Mission", International Journal of Business and Finance Management Research, 8-16

Rakesh, H. M. (2013) „Effect of IFRS and financial statements: implications on FDI and Indian economy", International Journal of Commerce, Business and Management, pp. 233-241

Rivera, J. (1990) „International Accounting Standards Harmonization and the Role of IASC”, Paper Presented to the XIII Annual Congress of the European Accounting Association

Rivera, J. M. (1989) „The internationalization of Accounting Standards: Past problems and current perspectives", International Journal of Accounting, pp. 320-342

Shima, K. M., \& Yang, D. C. (2012) „Factors affecting the adoption of IFRS”, International Journal of Business, pp. 276-298

Tan, H., Wang, S. \& Welker, M. (2011) „Analyst following and forecast accuracy after mandated IFRS adoptions", Journal of Accounting Research, vol. 49: $1307-1357$

Terzi, S., Oktem, R., \& Sen, I. K. (2013) „Impact of adopting international financial reporting standards: empirical evidence from Turkey", International Business Research, vol.6, no.4: 55-66

Uwubanmwem, A. E., \& Ajao, M. G. (2012) „The determinants and impacts of foreign direct investment in Nigeria", International Journal of Business and Management, vol. 7: 67-77

Uwuigbe, U., Erin, O., Uwuigbe, O., Peter, A. \& Jinadu, O. (2017) „IFRS and stock market behavior: An emerging market experience", Corporate Ownership and Control, vol.14, no.4: 93-102

Walker, M. (2010) „Accounting for varieties of capitalism: the case against a single set of global accounting standards", The British Accounting Review, vol. 42: $137-152$

Winney, K., Marshall, D., Bender, B., \& Swiger, J. (2010) „Accounting globaliztion:roadblocks to IFRS adoption in the United States", Global Review of Accounting and Finance, vol. 1: 167-178

Yip, R.W. Y. \& Young, D. (2012) "Does Mandatory IFRS Adoption Improve Information Comparability?", The Accounting Review, vol.87, no. 5: $1767-1789$ 


\section{Appendix A}

\section{Sample of research questionnaire}

1. Years of service in the organization:below 5 years ( ) between 5-10years( )above 10years ( )

2. Professional qualification:FCA ( )ACA( )Foundation Lvl( ) Skills Lvl ( ) Professional Lvl ( )

3. Interaction with the financial statement: Preparer ( ) User ( )

Select the appropriate answer:

SA-Strongly Agree, A-Agree , D- Disagree, SD- Strongly Disagree, U-Undecided

\begin{tabular}{|c|c|c|c|c|c|c|}
\hline $\mathrm{S} / \mathrm{N}$ & IFRS and Portfolio Investment & $\mathbf{S A}$ & $\mathbf{A}$ & D & SD & $\mathbf{U}$ \\
\hline 4 & $\begin{array}{l}\text { There is a relationship between IFRS and portfolio } \\
\text { investment in Nigeria }\end{array}$ & & & & & \\
\hline 5 & $\begin{array}{l}\text { Since the adoption of IFRS in Nigeria, there have been an } \\
\text { increase in the foreign participation of non-controlling } \\
\text { equity in Nigeria }\end{array}$ & & & & & \\
\hline \multirow[t]{2}{*}{6} & $\begin{array}{l}\text { The level of portfolio investment in Nigeria is determined } \\
\text { to a great extent by the financial reports prepared and } \\
\text { published in Nigeria }\end{array}$ & & & & & \\
\hline & IFRS and foreign direct investment in Nigeria & & & & & \\
\hline 7 & $\begin{array}{l}\text { There is a relationship between IFRS and foreign direct } \\
\text { investment in Nigeria }\end{array}$ & & & & & \\
\hline 8 & $\begin{array}{l}\text { Since the adoption of IFRS in Nigeria, there have been an } \\
\text { increase in the foreign participation of controlling equity } \\
\text { in Nigeria }\end{array}$ & & & & & \\
\hline 9 & $\begin{array}{l}\text { The level of foreign direct investment in Nigeria is } \\
\text { determined to a great extent by the financial reports } \\
\text { prepared and published in Nigeria }\end{array}$ & & & & & \\
\hline
\end{tabular}

\section{Appendix B}

Foreign portfolio investment of Nigeria for Q1 to Q4 of 2007-2016

\begin{tabular}{|l|l|l|l|l|}
\hline & Q1 & Q2 & Q3 & Q4 \\
\hline & \$ million & \$ million & \$ million & \$ million \\
\hline 2007 & $2,055.63$ & $1,922.81$ & $2,133.38$ & $2,395.81$ \\
\hline 2008 & $2,671.44$ & $2,350.26$ & $2,400.40$ & $2,562.47$ \\
\hline 2010 & $2,583.80$ & $2,778.07$ & $2,854.96$ & $2,469.24$ \\
\hline 2011 & $1,052.18$ & 820.05 & 903.01 & $1,091.67$ \\
\hline 2012 & $1,015.09$ & $1,364.12$ & $1,094.65$ & $1,039.26$ \\
\hline
\end{tabular}


IFRS adoption and cross border investment in Nigeria

\begin{tabular}{|l|c|c|c|c|}
\hline & \multicolumn{1}{|c|}{ Q1 } & \multicolumn{1}{|c|}{ Q2 } & \multicolumn{1}{c|}{ Q3 } & Q4 \\
\hline & \$ million & \$ million & \$ million & \$ million \\
\hline 2013 & $5,750.51$ & $4,487.50$ & $3,735.48$ & $3,395.76$ \\
\hline 2014 & $2,869.19$ & $4,917.13$ & $5,127.75$ & $2,003.10$ \\
\hline 2015 & $1,860.65$ & $2,183.15$ & $1,009.13$ & 952.50 \\
\hline 2016 & 271.03 & 337.31 & 920.32 & 284.22 \\
\hline
\end{tabular}

(Source: Nigeria Bureau of Statistics database)

\section{Appendix C}

Foreign direct investment of Nigeria for Q1 to Q4 of 2007-2016

\begin{tabular}{|l|c|c|c|c|}
\hline & Q1 & Q2 & Q3 & Q4 \\
\hline & \$ million & \$ million & \$ million & \$ million \\
\hline 2007 & 667.88 & $1,070.11$ & $1,689.54$ & 854.05 \\
\hline 2009 & $1,225.24$ & $1,746.31$ & 712.43 & 977.30 \\
\hline 2010 & $1,399.44$ & $1,071.53$ & $1,180.11$ & $1,569.65$ \\
\hline 2011 & 73.93 & 212.21 & 299.29 & 143.50 \\
\hline 2012 & 553.73 & 469.53 & 340.18 & 389.90 \\
\hline 2013 & 524.76 & 214.24 & 421.16 & 839.71 \\
\hline 2014 & 561.42 & 400.91 & 195.28 & 121.82 \\
\hline 2015 & 490.69 & 472.99 & 544.50 & 768.86 \\
\hline 2016 & 174.46 & 211.14 & 717.71 & 123.16 \\
\hline
\end{tabular}

(Source: Nigeria Bureau of Statistics database) 